\title{
Evaluasi penerapan pajak daerah online menggunakan aplikasi e-PAD terhadap penerimaan pajak daerah Kabupaten Banyuwangi tahun 2020
}

\author{
Riza Firmansyah, Agus Sumanto* \\ Universitas Negeri Malang, Jl. Semarang No. 5 Malang, Jawa Timur, Indonesia \\ *Penulis korespondensi, Surel: agus.sumanto.fe@um.ac.id
}

Paper received: 5-7-2021; revised: 23-7-2021; accepted: 30-7-2021

\begin{abstract}
Regional taxes are the flow of assets from individuals or entities that are used as contributions to local governments without getting direct benefits with a forced collection process which is then used to finance the implementation of regional expenditures. The legal basis for collecting Regional Taxes and Regional Levies is Law Number 28 the year 2009 was a refinement of Law Number 34 of 2000. As a form of implementing non-cash transactions, the Banyuwangi Regency Government implemented an online sistem in the process of collecting and monitoring local taxes with an application called electronic-Regional Original Income (e-PAD. This study aims to evaluate the application of the local tax online sistem in Banyuwangi Regency using a policy evaluation method with six indicators, namely effectiveness, efficiency, adequacy, smoothing, responsiveness, and accuracy. Documentation, observation, and interviews. The results of the study show that the application of technology in the form of an E-PAD tax payment application is considered quite good and is considered quite acceptable among the community, although there are still many people who still do not want to use this E-PAD application and it is expected that users of this application will increase. The collection before the application was very ineffective due to the complexity of the tax payment process with separate SKPDs. Evaluation of the implementation of the second phase of the online sistem can be seen from 6 indicators showing that the overall sistem has been running well and has had a positive impact on users, but there are still obstacles to this online sistem for both parties, both taxpayers and tax collectors.
\end{abstract}

Keywords: online sistem; local tax; policy evaluation

\begin{abstract}
Abstrak
Pajak daerah ialah aliran harta dari orang pribadi atau badan yang dijadikan sebagai kontribusi terhadap pemerintah daerah tanpa mendapatkan manfaat secara langsung dengan proses penagihan yang bersifat memaksa yang kemudian untuk membiayai penyelenggaraan belanja daerah.Landasan hukum pemungutan Pajak Daerah dan Retribusi Daerah yaitu Undang-Undang Nomor 28 Tahun 2009 merupakan penyempurnaan dari Undang-Undang Nomor 34 Tahun 2000. Sebagai bentuk implementasi transaksi non tunai, Pemerintah Kabupaten Banyuwangi menerapkan sistem online dalam proses pemungutan dan pengawasan pajak daerah dengan aplikasi yang bernama electronicPendapatan Asli Daerah (e-PAD). Penelitian ini bertujuan untuk mengevaluasi penerapan sistem online pajak daerah di Kabupaten Banyuwangi menggunakan metode evaluasi kebijakan dengan enam indikator yakni efektivitas, efisiensi, kecukupan, perataan, responsivitas, dan ketepatan. Penelitian ini merupakan penelitian kualitatif dimana sumber data diperoleh dengan cara dokumentasi, observasi, dan wawancara. Hasil Penelitian menunjukan bahwa Penerapan teknologi berupa aplikasi pembayaran pajak E-PAD dirasa cukup baik dan dirasa cukup di terima di kalangan masyarakat, meskipun masih banyak masyarakat yang masih belum mau untuk menggunakan aplikasi E-PAD ini dan diharapkan pengguna dari aplikasi ini meningkat. Pemungutan sebelum adanya aplikasi ini sangat tidak efektif dikarenakan masih rumitnya proses pembayaran pajak dengan SKPD yang terpisah-pisah. Evaluasi penerapan sistem online tahap dua dapat dilihat dari 6 indikator menunjukkan bahwa secara keseluruhan sistem sudah berjalan dengan baik dan memberikan dampak positif bagi pengguna, namun masih ditemui adanya kendala sistem online ini bagi kedua belah pihak baik Wajib Pajak maupun pemungut pajak.
\end{abstract}

This work is licensed under a Creative Commons Attribution-ShareAlike 4.0 International License. 
Kata kunci: sistem online; pajak daerah; evaluasi kebijakan

\section{Pendahuluan}

Pendapatan Asli Daerah (PAD) merupakan aspek penting pemerintahan daerah dalam menjalankan urusan pemerintahannya. Wewenang pemerintah pusat menjadi terbatas dengan adanya otonomi daerah. Hal ini didasari oleh semakin besar dan bermacam-macam kebutuhan dan banyaknya persoalan masyarakat sehingga kebutuhan desentralisasi semakin diperlukan. Menurut Undang-Undang Nomor 23 Tahun 2014 pasal 1 desentralisasi adalah penyerahan wewenang pemerintahan oleh pemerintah pusat pada pemerintah daerah berdasarkan asas otonomi. Pengelolaan keuangan di Indonesia berubah sejak diterapkannya otonomi daerah, menurut Undang-Undang Nomor 32 Tahun 2004 tentang pemerintah daerah yaitu memberikan kewenangan kepada pemerintah daerah untuk mendanai otonomi daerahnya sesuai dengan potensi daerah yang ada sebagai perwujudan desentralisasi.

Pajak daerah, retribusi daerah, hasil pengelolaan kekayaan daerah, dan pendapatan daerah lain-lain yang sah merupakan komponen pendapatan asli daerah. Pajak daerah merupakan sumber pendapatan asli daerah yang dipungut untuk membiayai keperluan daerah yang utama dan sangat penting bagi pemerintah daerah berdasarkan peraturan yang ditetapkan oleh pemerintah daerah (Mardiasmo, 2018). Pajak daerah menurut UndangUndang Nomor 28 Tahun 2009 tentang pajak daerah dan retribusi daerah, pajak daerah terbagi menjadi dua yaitu pajak provinsi dan pajak kabupaten/kota.

Pengaruh perkembangan dan penerapan teknologi dan informasi saat ini telah diimplementasikan pada sektor pemerintahan salah satunya di bidang perpajakan. Keterkaitan antara pelaksana kewajiban perpajakan oleh wajib pajak dengan pelayanan perpajakan yang baik agar dapat tercapainya kepatuhan pajak, berpengaruh terhadap realisasi penerimaan pajak, khususnya bagi realisasi pendapatan asli daerah agar mencapai target yang telah ditentukan. Diperlukan integrasi antara administrasi pajak dengan teknologi dan informasi agar dapat tercapainya suatu pelayanan pajak yang modern, fleksibel, dan akuntabel. Permasalahan yang biasa terjadi dalam proses pembayaran pajak sebelum adanya sistem online pajak daerah E-PAD yaitu rumitnya alur pembayaran pajak daerah yang bagi masyarakat cukup berbelit dan dengan antrian pembayaran yang terkadang cukup lama sehingga tidak adanya efisiensi waktu lalu proses pembayarannya pun masih manual. Disisi lain dengan adanya keputusan Pemerintah Kabupaten Banyuwangi membagi pengelolaan pajak dan retribusi daerah juga merumitkan para wajib pajak.

Menindaklanjuti Peraturan Pemerintah Kabupaten Banyuwangi Nomor 2 Tahun 2018 Tentang Implementasi Transaksi Non Tunai, Badan Pendapatan Daerah Kabupaten Banyuwangi telah mulai menerapkan Sistem Online Pajak Daerah Daerah dengan nama aplikasi E-PAD (electronic - Pendapatan Asli Daerah) pada tahun 2018. Aplikasi tersebut dapat diakses oleh Wajib Pajak melalui web atau sistem operasi android yang dapat diunduh di Playstore. Aplikasi E-PAD memiliki beberapa fitur, yakni E-Find, Pendaftaran Wajib Pajak, Pembayaran Tagihan, Informasi Pajak Daerah, SPTPD online, serta data Nomor Pokok Wajib Pajak Daerah, Nomor Objek Pajak Daerah dan perekaman Surat Ketetapan Pajak.

Peluncuran aplikasi E-PAD dilakukan untuk memberikan kemudahan bagi wajib pajak dalam membayar kewajiban perpajakannya. Dengan diciptakanya aplikasi ini juga sebagai 
bentuk komitmen daerah dalam pemanfaatan teknologi informasi dan komunikasi di segala bidang. Penggunaan sistem online pajak daerah juga diharapkan mampu meningkatkan transparansi dan akuntabilitas penerimaan pajak, karena semua aktivitas telah tersistem maka penerimaan pajaknya juga dapat dilihat laporannya. Penggunaan sistem online dalam pemungutan pajak juga bertujuan mengintegrasikan daftar wajib pajak. Sebagian wajib pajak memiliki tagihan beberapa pajak sekaligus, yang selama ini tagihannya masih terpisah-pisah. Pada sistem E-PAD, semua kewajiban pajak seseorang terhimpun menjadi satu. Bahkan riwayat pembayaran pajak sebelumnya juga bisa terlihat.

\subsection{KAJIAN PUSTAKA}

\subsubsection{Pajak}

Menurut Undang-Undang No. 28 Tahun 2009 pajak merupakan kontribusi wajib kepada negara yang terutang oleh orang pribadi atau badan yang bersifat memaksa berdasarkan Undang- Undang, dengan tidak mendapatkan manfaat secara langsung dan digunakan untuk keperluan negara bagi sebesar-besarnya kemakmuran rakyat. Kemudian menurut Soemitro dikutip dari Rismawati, dkk (2012:2) pajak merupakan iuran wajib terhadap kas negara yang berdasar pada Undang-Undang yang berlaku yang dipaksakan dengan tidak mendapatkan kontraprestasi (timbal balik) yang secara langsung ditujukan ke rakyat, dan digunakan sebagai pengeluaran negara.

\subsubsection{Jenis Pajak}

Menurut Siti Remi (2011:7), jenis pajak berdasarkan Lembaga Pemungut Pajak dibagi menjadi dua, yaitu: (1) Pajak Negara: pajak yang dipungut oleh pemerintah pusat dan digunakan sebagai penyelenggara rumah tangga negara. (2) Pajak Daerah: pajak yang dipungut oleh pemerintah daerah baik tingkat I (pajak provinsi) maupun daerah tingkat II (pajak kabupaten/kota) dan digunakan sebagai penyelenggaraan rumahtangga daerah masing-masing.

\subsubsection{Pajak Daerah}

Menurut Suandy (2016:229) Pajak daerah ialah aliran harta dari orang pribadi atau badan yang dijadikan sebagai kontribusi terhadap pemerintah daerah tanpa mendapatkan manfaat secara langsung dengan proses penagihan yang bersifat memaksa yang kemudian untuk membiayai penyelenggaraan belanja daerah. Landasan hukum pemungutan Pajak Daerah dan Retribusi Daerah yaitu Undang-Undang Nomor 28 Tahun 2009 merupakan penyempurnaan dari Undang-Undang Nomor 34 Tahun 2000. Jenis Pajak Daerah meliputi pajak provinsi dan pajak kabupaten/kota.

\subsubsection{Sistem Pemungutan Pajak Daerah}

Menurut Rosdiana dan Edi (2018), penetapan pemungutan pajak dapat dilaksanakan dengan 3 sistem berikut: 


\subsubsection{Self Assessment Sistem}

Pada sistem pemungutan ini para wajib pajak ini dituntut untuk aktif dalam melaksanakan kewajiban perpajakannya, dimulai dari menghitung pajaknya, melaporkan pendapatannya, serta membayar pajak terutang dirinya. Dalam hal ini fiskus hanya sebagai pengawas dalam segala hal yang dilakukan oleh para wajib pajak.

\subsubsection{Official Assessment Sistem}

Berbeda dari sistem Self Assessment sistem ini merupakan kebalikannya dimana besaran jumlah pajak yang wajib dibayarkan ditentukan dan ditetapkan oleh fiskus.

\subsubsection{Without Sistem atau Semi-Self Assessment}

Dalam sistem yang terakhir ini pajak dipungut oleh pihak ketiga yang diberikan kekuasaan dimana sudah ditentukan sebelumnya dan mampu dipercaya dalam menentukan besarnya pajak yang masih harus dibayarkan pada setiap periodenya.

\subsubsection{Sistem Administrasi Pajak Modern}

Pemerintah melalui Direktorat Jenderal Pajak (DJP) terus memberikan inovasi dalam mengoptimalkan penerimaan pajak melalui kebijakan-kebijakan yang dikeluarkan. Salah satunya adalah dengan melakukan reformasi perpajakan (tax reform), tujuan dari reformasi perpajakan ini adalah untuk meningkatkan administrasi perpajakan yang transparan, akuntabel, dan memanfaatkan teknologi dan informasi (DJP, 2007). Konsep modernisasi merupakan sebuah inovasi yang kedepanya akan membawa perubahan dalam administrasi perpajakan itu sendiri.

Tujuan dari modernisasi sendiri adalah untuk meningkatkan kepatuhan wajib pajak dalam menyelesaikan perpajakannya, meningkatkan kepercayaan masyarakat, dan meningkatkan tingkat keproduktivitas dan integrasi pegawai pajak (DJP, 2007), adapun perubahan-perubahan yang tengah digalakkan sebagai bentuk modernisasi administrasi perpajakan adalah sebagai berikut: (1) Penataan kembali struktur organisasi. (2) Pembaruan sistem berbasis teknologi dan informasi. (3) Perbaikan sistem manajemen sumber daya manusia. (4) Penyelenggaraan good governance.

\subsubsection{Pelayanan Publik}

Pelayanan publik merupakan tumpuan birokrasi yang langsung berhadapan dengan masyarakat. Berdasarkan keputusan MENPAN Nomor 63 Tahun 2003, menjelaskan bahwa pelayanan publik sebagai segala kegiatan pelayanan yang dilaksanakan oleh penyelenggara pelayanan publik sebagai upaya pemenuhan kebutuhan penerima pelayanan maupun pelaksanaan ketentuan peraturan perundang-undangan. Menurut Undang-Undang Nomor 25 Tentang Pelayanan Publik menjelaskan bahwa pelayanan publik adalah kegiatan atau rangkaian kegiatan pemenuhan kebutuhan pelayanan sesuai peraturan perundang-undangan bagi setiap warga negara dan penduduk atas barang, jasa, dan/atau pelayanan administratif yang disediakan oleh penyelenggara pelayanan publik. 
Menurut Ratminto dan Atik Septi Winarsih (2006) pelayanan publik merupakan sebagai bentuk pelayanan pada masyarakat yang berbentuk barang publik maupun jasa publik yang pada intinya merupakan suatu tanggung jawab dan diselenggarakan oleh instansi pemerintah pusat, daerah, dan lingkungan Badan Usaha Milik Negara ataupun Badan Usaha Milik Daerah, sebagai bentuk upaya pemenuhan kebutuhan masyarakat maupun dalam pelaksanaan yang mengacu pada perundang-undangan.

\subsubsection{Teori Evaluasi Kebijakan}

Evaluasi kebijakan adalah kegiatan yang menyangkut estimasi atau penilaian kebijakan yang mencakup substansi, implementasi dan dampak. Evaluasi kebijakan dilihat sebagai suatu kegiatan fungsional. Artinya, evaluasi kebijakan tidak hanya dilakukan pada tahap akhir saja melainkan pada seluruh proses kebijakan. Evaluasi kebijakan ditujukan untuk menilai keefektifan suatu kebijakan publik agar dapat dipertanggungjawabkan konstituennya. Menurut William, N. Dunn (1999) dalam (Nugroho, 2012), istilah evaluasi dapat disamakan dengan penaksiran (appraisal), pembagian angka (rating), dan penilaian (assessment). Evaluasi berkenaan dengan menghasilkan informasi yang valid dan manfaat hasil kebijakan. Evaluasi dapat memberikan informasi yang valid dan dapat dipercaya mengenai kinerja kebijakan, yaitu seberapa valid dan dapat dipercaya mengenai kinerja kebijakan, yaitu seberapa valid kebutuhan, nilai, dan kesempatan telah mampu diraih melalui tindakan dari kebijakan publik; memberikan sumbangan pada klarifikasi dan kritik terhadap nilai-nilai yang mendasari pemilihan tujuan target; memberikan sumbangan pada aplikasi metode-metode analisis kebijakan lainnya, termasuk juga perumusan masalah dan rekomendasi. Meskipun berkenaan dengan keseluruhan proses kebijakan, evaluasi lebih berkenaan dengan kinerja dari kebijakan, khususnya pada implementasi kebijakan (Nugroho, 2014). Evaluasi kebijakan memainkan peran penting dalam memberikan umpan balik tentang apa yang terjadi dalam suatu program/praktik/teknologi berkaitan dengan suatu kebijakan (Trochim, 2009). Evaluasi kebijakan juga memandu bagaimana evaluasi dilakukan. Evaluasi kebijakan memuat sejumlah aturan dan prinsip yang menentukan kelompok atau organisasi menggunakan panduan keputusan dan tindakan ketika melakukan evaluasi.Evaluasi kebijakan dipandang penting, karena evaluasi bernilai sebagai peran penanda dengan tipe-tipe mekanisme yang diperlihatkan. Evaluasi kebijakan merupakan penanda bagi seluruh organisasi dan stakeholder tentang apa yang terjadi dan apa yang harus dilakukan.

Mengevaluasi dampak atas suatu program atau kebijakan diperlukan adanya suatu kriteria untuk mengukur keberhasilan program atau kebijakan tersebut. Menurut Dunn yang dikutip dari Eko Handoyo (2012), kriteria dalam mengevaluasi program atau kebijakan dapat dikategorikan sebagai berikut:

\subsubsection{Efektivitas}

Menurut Masruri (2017) efektivitas adalah seberapa baik pekerjaan yang dilakukan, sejauh mana orang menghasilkan sesuatu dari target yang sudah ditentukan. Hal ini berarti apabila suatu pekerjaan dapat diselesaikan sesuai dengan yang direncanakan, baik dalam waktu maupun biaya, maka dapat dikatakan efektif. 


\subsubsection{Efisiensi}

Kriteria ini membandingkan pengorbanan yang dikeluarkan untuk pencapaian tujuan program atau kebijakan dengan hasil yang diperoleh.

\subsubsection{Kecukupan}

Kecukupan dalam kebijakan publik dapat dikatakan tujuan yang telah dicapai sudah dirasakan mencukupi dalam berbagai hal. Kecukupan (adequacy) berkenaan dengan seberapa jauh suatu tingkat efektivitas memuaskan kebutuhan, nilai, atau kesempatan yang menumbuhkan adanya masalah.

\subsubsection{Perataan}

Perataan dalam kebijakan publik dapat dikatakan mempunyai arti dengan keadilan yang diberikan dan diperoleh sasaran kebijakan publik. Kebijakan yang berorientasi pada perataan adalah kebijakan yang akibatnya atau usaha secara adil didistribusikan. Suatu program tertentu mungkin dapat efektif, efisien, dan mencukupi apabila biaya-manfaat merata.

\subsubsection{Responsivitas}

Kriteria responsivitas merupakan cerminan nyata kebutuhan, preferensi, dan nilai dari kelompok tertentu terhadap kriteria efektivitas, efisiensi, kecukupan, dan kesamaan.

\subsubsection{Ketepatan}

Ketepatan merujuk pada nilai dari tujuan program atau kebijakan juga asumsi yang melandasi tujuan-tujuan tersebut. Kriteria kelayakan dihubungkan dengan rasionalitas substantif, karena kriteria ini menyangkut substansi tujuan bukan cara atau instrumen untuk merealisasikan tujuan tersebut.

\section{Metode}

Pelaksanaan penelitian tentang Evaluasi Penerapan Pelayanan Pajak Daerah Online Menggunakan Aplikasi E-PAD Terhadap Penerimaan Pajak Daerah di Kabupaten Banyuwangi Tahun 2020 menggunakan pendekatan kualitatif, penelitian ini merupakan penelitian deskriptif, dimana penelitian ini bertujuan untuk mengevaluasi penggunaan sistem pajak online menggunakan teori evaluasi kebijakan. Pendekatan kualitatif adalah metode untuk mengeksplorasi dan mendokumentasikan keadaan sosial secara mendalam dan menyeluruh. Sugiyono (2015) menyatakan bahwa penelitian kualitatif merupakan jenis penelitian yang berlandaskan pada filsafat postpositivisme, digunakan untuk meneliti pada kondisi yang alamiah, secara sederhana dapat dinyatakan bahwa penelitian kualitatif adalah meneliti informan sebagai subjek penelitian. Alasan menggunakan metode deskriptif kualitatif karena peneliti dapat mengenal dan berinteraksi langsung dengan subyek penelitian. Berinteraksi langsung dengan subyek akan membuat penelitian lebih mendalam dan data yang didapatkan akurat dan orisinil. Dalam penelitian ini peneliti mencoba menggambarkan kebijakan dalam hal ini aplikasi E-PAD terhadap peningkatan pajak daerah kabupaten banyuwangi. Melalui pengumpulan data yang detail dan mendalam yang melibatkan beragam sumber informasi atau sumber informasi baik internal maupun eksternal misalnya pengamatan, wawancara, dan observasi. 
Lokasi penelitian merupakan tempat peneliti untuk melakukan penelitian dan untuk mengetahui keadaan yang sebenarnya agar data atau informasi yang dibutuhkan mencerminkan keadaannya yang sebenarnya. Lokasi penelitian Evaluasi Penerapan Pelayanan Pajak Daerah Online Menggunakan Aplikasi E-PAD Terhadap Penerimaan Pajak Daerah di Kabupaten Banyuwangi Tahun 2020, tepatnya di Badan Pendapatan Daerah Kabupaten Banyuwangi (Bapenda). Pengumpulan data merupakan suatu langkah yang sangat penting dalam penelitian, oleh karena itu peneliti harus terampil dalam mengumpulkan data yang valid dan nyata. Adapun teknik pengumpulan data yang dilakukan dalam penelitian ini adalah sebagai berikut: (1) Wawancara, (2) Observasi, (3) Dokumentasi. Menurut Sugiyono (2015) analisis data adalah proses mencari dan menyusun secara sistematis data yang diperoleh dari hasil wawancara, catatan lapangan, dan dokumentasi dengan cara mengorganisasikan data ke dalam kategori, menjabarkan ke dalam satuan-satuan, melakukan sintesa, menyusun kedalam pola, memilih mana yang penting dan yang akan dipelajari, dan membuat kesimpulan sehingga mudah dipahami oleh diri sendiri maupun orang lain.

Untuk menganalisis data menggunakan model analisis interaktif dari Miles dan Huberman, model interaktif ini terdiri dari tiga hal utama yaitu reduksi data, penyajian data, dan penarikan kesimpulan/verifikasi. Menurut Miles dan Huberman (dalam Sugiyono, 2015) merupakan sebuah aktivitas menganalisis data kualitatif dengan cara interaktif dan berlangsung secara terus menerus hingga tuntas, sehingga datanya sudah jenuh. Agar dapat memenuhi validitas data dalam penelitian, maka pengecekan keabsahan data penelitian perlu dilakukan agar memperoleh kredibilitas dari hasil penelitian yaitu dengan menggunakan Triangulasi. Triangulasi yang digunakan dalam penelitian ini antara lain yaitu Triangulasi Sumber Data dan Triangulasi Metode.

\section{Hasil dan Pembahasan}

Badan Pendapatan Daerah Kabupaten Banyuwangi merupakan unsur pelaksana bidang pemerintahan, pembangunan dan kemasyarakatan, yang dipimpin oleh Kepala Badan yang berkedudukan di bawah dan bertanggung jawab kepada Bupati melalui Sekretaris Daerah. Badan Pendapatan Daerah Kabupaten Banyuwangi mempunyai tugas melaksanakan kewenangan otonomi daerah dibidang pendapatan, berdasarkan asas otonomi dan tugas pembantuan yang diberikan oleh Pemerintah Kabupaten Banyuwangi. Tugas pokok dan fungsi Badan Pendapatan Daerah Kabupaten Banyuwangi, mengacu pada Peraturan Daerah Kabupaten Banyuwangi Nomor 3 Tahun 2019 Tentang Kedudukan, Susunan Organisasi, Tugas dan Fungsi Serta Tata Kerja Badan Pendapatan Daerah Kabupaten Banyuwangi. Tugas pokok Badan Pendapatan Daerah, pada dasarnya adalah membantu Bupati dalam penyelenggaraan Pemerintahan, khususnya bidang pendapatan.

\subsection{Mekanisme pemungutan pajak sebelum dan sesudah adanya sistem online pajak daerah aplikasi E-PAD}

Sebelum penggunaan Aplikasi e-PAD dalam pemungutan Pajak Daerah, Wajib Pajak merasakan prosedur yang cukup rumit dimana setelah mendatangi instansi terkait, Wajib Pajak harus menyelesaikan pembayaran dengan mendatangi Bank Jatim untuk menyelesaikan pembayaran pajak melalui teller Bank Jatim. Selama pelaksanaan pemungutan dan pengawasan Pajak Daerah sebelum diberlakukan Sistem Online Pajak Daerah terdapat beberapa kendala yang menghambat proses penerimaan Pajak Daerah., salah satunya yakni rumitnya prosedur pembayaran dan jarak yang harus ditempuh untuk menyelesaikan 
kewajiban perpajakannya. Pada tahun 2017, sejumlah jenis Pajak Daerah yang sebelumnya dikelola oleh Badan Pendapatan Daerah, bergeser ke sejumlah Satuan Kerja Perangkat Daerah (SKPD) sesuai dengan bidang masing masing. Contonya Pajak Hotel, Pajak Restoran, Pajak Hiburan dipungut oleh Dinas Kebudayaan dan Pariwisata, kemudian Pajak Penerangan Jalan dan Pajak Parkir pembayarannya dilakukan di Dinas Perhubungan. Dinas Perindustrian dan Perdagangan memungut Pajak Air Bawah Tanah dan Pajak Mineral Bukan Logam dan Batuan, dan Badan Pendapatan Daerah memungut Pajak Bumi dan Bangunan Perdesaan dan Perkotaan serta BPHTB. Akibat pelimpahan wewenang tersebut Wajib Pajak seringkali tetap mendatangi Kantor Badan Pendapatan Daerah untuk menyelesaikan kewajiban perpajakan yang bukan menjadi wewenang Badan Pendapatan Daerah.

Penerapan Sistem Online Pajak Daerah di Kabupaten Banyuwangi merupakan Aplikasi E-PAD merupakan pengembangan dari sistem keuangan daerah sebelumnya yang bernama SIMPADA. Aplikasi E-PAD dibuat untuk menyederhanakan proses pembayaran Pajak Daerah dengan memangkas kendala yang ditimbulkan akibat proses pembayaran Pajak Daerah, namun dalam pelaksanaannya tentu membutuhkan banyak evaluasi yang diperlukan guna mendapatkan sebuah Sistem Online Pajak Daerah yang sesuai. Efektivitas penggunaan aplikasi e-PAD merupakan tujuan utama dari pembuatan Sistem Online Pajak Daerah. Badan Pendapatan Daerah berharap dengan adanya aplikasi, Wajib Pajak merasakan dampak positif sehingga dapat menyelesaikan kewajiban perpajakannya dengan memanfaatkan inovasi teknologi dalam pemungutan dan pengawasan Pajak Daerah. Ada dua jenis pengguna dari sisi Wajib Pajak, yang pertama adalah user yang memiliki akun dalam aplikasi E-PAD, yang kedua adalah non user yang menggunakan aplikasi E-PAD sebatas mengecek jumlah pajak terutangnya. dalam pelaksanaan sosialisasi yang dilakukan oleh Badan Pendapatan Daerah belum memiliki pengaruh signifikan terhadap kesediaan Wajib Pajak untuk menggunakan aplikasi e-PAD. Penggunaan Sistem Online Pajak Daerah oleh Wajib Pajak yang memahami perkembangan teknologi pun memang didasari karena adanya keterbiasaan menggunakan sistem informasi dalam kegiatan manajemen usaha mereka.

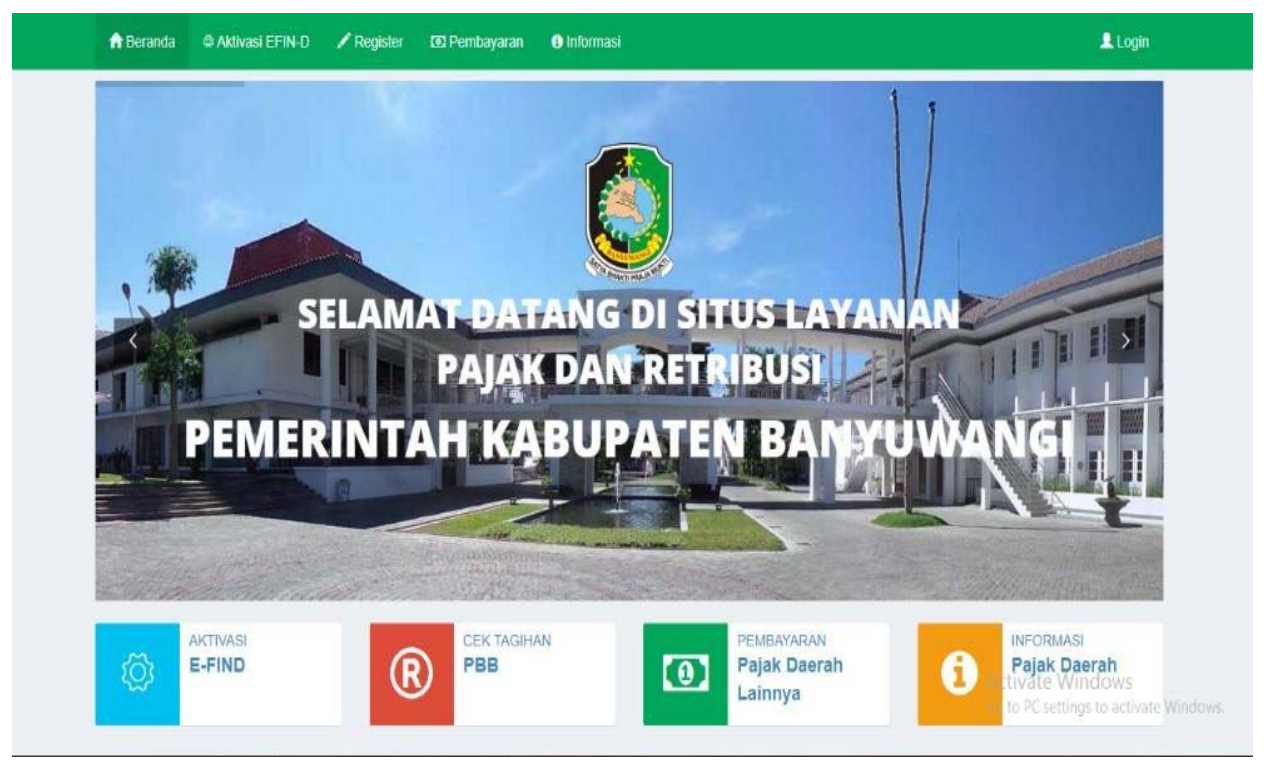

Gambar 1. Portal Wen E-PAD 
Prosedur untuk dapat mengakses aplikasi E-PAD dapat dilakukan dengan langkah mendaftarkan diri sebagai Wajib Pajak terlebih dahulu, setelah itu Wajib Pajak akan mendapatkan kode E- FIND untuk mengaktivasi akun Wajib Pajak di aplikasi e-PAD. User login menggunakan kode E-FIND tersebut, setelah itu Wajib Pajak harus mengisi Surat Pemberitahuan Pajak Daerah (SPTPD) sesuai dengan objek pajaknya. Bagian Validasi dan Penetapan Badan Pendapatan Daerah Banyuwangi akan memvalidasi/memverifikasi data yang dikirim oleh Wajib Pajak. Langkah terakhir akan muncul kode bayar SKPD dengan tanda tangan digital. Wajib Pajak melakukan pembayaran pajak terutang dengan menggunakan ID billing yang telah diperoleh melalui Bank Jatim. Metode pembayaran dilakukan adalah dengan menggunakan virtual account yang mana bisa dibayarkan melalui semua channel dari semua bank. Selanjutnya, apabila Wajib Pajak telah menyelesaikan pembayarannya maka transaksi pembayaran pajak akan terekam oleh sistem yang terintegrasi host to host dari Dinas Komunikasi, Informasi dan persandian. Aplikasi E-PAD merupakan bentuk layanan keuangan digital berbasis web dan android yang disediakan oleh Pemerintah Kabupaten Banyuwangi. Laman web aplikasi e-PAD dapat dilihat pada gambar diatas. Untuk layanan web aplikasi ePAD memiliki alur sebagai berikut:

Wajib Pajak masuk ke portal layanan keuangan digital Pemerintah Kabupaten Banyuwangi, kemudian melakukan pemesanan dan pengisian data lalu memilih pembayaran Pajak Daerah senilai jumlah terhutang, selanjutnya browser konsumen akan diarahkan ke metode pembayaran.

Wajib Pajak memilih metode pembayaran atau menentukan Source Of Fund yang akan digunakan, Source Of Fund berupa mobile banking, internet banking, ATM, teller, dan fasilitas lain yang disediakan oleh bank umum. Serta Payment Gateway akan meneruskan ke host source of fund yang dipilih untuk selanjutnya diproses.

Apabila proses transaksi berhasil, Payment Gateway akan langsung memberikan Paid Notification ke Backend sistem web layanan keuangan digital Pemerintah Kabupaten Banyuwangi.

Sistem web layanan keuangan digital Pemerintah Kabupaten Banyuwangi meneruskan ke proses flagging transaksi pembayaran dari Wajib Pajak

Wajib Pajak juga dapat melakukan pembayaran melalui aplikasi E-PAD berbasis android di mobile phone masing-masing Prosedur pembayaran tidak jauh berbeda dengan layanan web hanya saja pengguna aplikasi E-PAD berbasis android terlebih dahulu menginstal aplikasi dari playstore. Portal layanan pembayaran Pajak Daerah melalui aplikasi E-PAD berbasis android dapat dilihat pada Gambar berikut ini. 


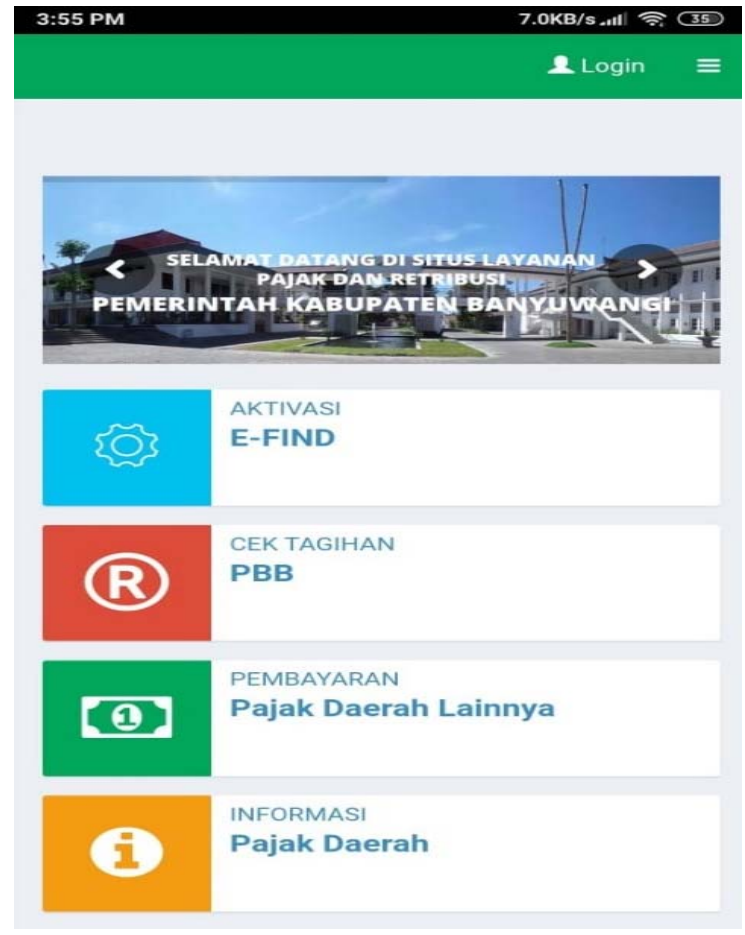

Gambar 2. Portal Android E-PAD

\subsection{Evaluasi kebijakan penerapan sistem online pajak daerah E-PAD}

Kecakapan dalam menggunakan teknologi sangat mempengaruhi tingkat penggunaan Sistem Online Pajak Daerah, untuk itu dalam upaya menerapkan Sistem Online Pajak Daerah secara menyeluruh di Kabupaten Banyuwangi membutuhkan waktu. Berbagai langkah dilakukan oleh Badan Pendapatan Daerah untuk menciptakan pemerataan atas penggunaan aplikasi E-PAD. Oleh karena itu, selain dengan melakukan sosialisasi kepada Wajib Pajak Penerapan sistem pajak daerah online sendiri sudah cukup efektif sebagai faktor pendapatan daerah. Karena beberapa fitur yang diberikan sangat mudah diakses oleh para wajib pajak, Jika dibandingkan dengan sistem yang terdahulu, sistem yang sekarang dipergunakan lebih baik karena selain sudah terintegrasi ke Pemerintah Kabupaten yaitu Badan Pendapatan Daerah sistem ini sudah langsung membayar atau autodebet ke bank yang bekerjasama dengan Pemerintah Daerah secara otomatis dalam hal ini Bank Jatim. Kemudian dilihat dari sisi perataan, awalnya Badan Pendapatan Daerah Kabupaten Banyuwangi menargetkan 80\% masyarakat mampu mengoperasikan aplikasi ini, namun masih banyak para wajib pajak yang masih takut data-datanya akan bocor. Jadi masih perlu diadakan sosialisasi lebih intens untuk meyakinkan para wajib pajak untuk menggunakan aplikasi E-PAD ini agar target dari pemerataan pengguna aplikasi ini dapat tercapai. Dari indicator responsivisitas masih ada beberapa wajib pajak mengeluh mengenai aplikasi yang dijalankan masih sering error, namun dari pihak Badan Pendapatan Daerah dan Dinas Komunikasi dan Persandian terus meningkatkan aplikasi ini dengan baik dengan melakukan perawatan yang sudah ada dananya. Dari indikator ketepatan sasaran dari pengguna aplikasi ini masih belum dikatakan tepat. Ini dibuktikan masih banyak dari wajib pajak terutama yang menengah kebawah untuk menggunakan aplikasi E-PAD ini. Namun pihak Badan Pendapatan Daerah tetap gencar melakukan sosialisasi agar para masyarakat mau dan percaya untuk menggunakan aplikasi E- 
PAD ini. Untuk indicator terakhir dari evaluasi kebijakan penerapan sistem online pajak daerah penyempurnaan sistem aplikasi pajak daerah online E-PAD ini setiap tahunnya terus digencarkan untuk pembaruan dan perawatan sistem sesuai anggaran yang disiapkan pemerintah Kabupaten Banyuwangi. Kemudian adanya jaminan kerahasiaan data wajib pajak, jadi tidak semerta-merta semua pegawai yang ada di Badan Pendapatan Daerah bias mengakses data dari wajib pajak yang ada di sistem E-PAD ini, dan yang terakhir ialah mengenai kesiapan dari para wajib pajak untuk menerima teknologi terbaru dalam sistem pembayaran pajak daerah online ini.

\section{Simpulan}

Penerapan teknologi berupa aplikasi pembayaran pajak E-PAD dirasa cukup baik dan dirasa cukup di terima di kalangan masyarakat, meskipun masih banyak masyarakat yang masih belum mau untuk menggunakan aplikasi E-PAD ini dan diharapkan pengguna dari aplikasi ini meningkat. Pemungutan sebelum adanya aplikasi ini sangat tidak efektif dikarenakan masih rumitnya proses pembayaran pajak dengan SKPD yang terpisah-pisah. Evaluasi penerapan sistem online tahap dua dapat dilihat dari 6 indikator menunjukkan bahwa secara keseluruhan sistem sudah berjalan dengan baik dan memberikan dampak positif bagi pengguna, namun masih ditemui adanya kendala sistem online ini bagi kedua belah pihak baik Wajib Pajak maupun pemungut pajak.

\section{Daftar Rujukan}

Atik Septi Winarsih, Ratminto. (2006). Manajemen Pelayanan. Yogyakarta: Pustaka Pelajar.

Handoyo, Eko. (2012). Kebijakan Publik. Semarang: Widya Karya.

Indonesia, P. R. (2000). Undang-Undang Nomor 34 Tahun 2000 tentang Perubahan atas Undang-Undang Republik Indonesia Nomor 18 Tahun 1997 tentang Pajak dan Retribusi Daerah. Jakarta: Sekretariat Negara.

Indonesia, R. (2007). Undang-Undang Nomor 32 Tahun 2004 tentang Pemerintahan Daerah. Pustaka Yustisia.

Indonesia, R. (2009). Undang-Undang Nomor 28 Tahun 2009 tentang Pajak Daerah dan Retribusi Daerah. Jakarta: Sekretariat Negara.

Masruri, M., \& Muazansyah, I. (2017). Analisis efektifitas program nasional pemberdayaan masyarakat mandiri perkotaan (PNPM-MP). Journal of Governance and Public Policy, 4(2), 363-393.

Mardiasmo. (2018). Perpajakan, Edisi Terbaru 2018. Yogyakarta: C.V Andi Offset.

Nomor, K. M. P. A. N. (63). tahun 2003 tentang pedoman umum penyelenggaraan pelayanan publik. Jakarta, Kementerian Pendayagunaaan Aparatur Negara.

Nomor, U. U. R. I. (32). tahun 2004 tentang Pemerintahan Daerah.

Pemerintah, R. I. (2007). Undang-Undang No. 28 tahun 2007 tentang Perubahan Ketiga atas Undang-undang No. 6 tahun 1983 tentang Ketentuan Umum dan Tata Cara Perpajakan.

Peraturan Bupati Banyuwangi (2018) Nomor 2 Tahun 2018 tentang Implementasi Transaksi Non Tunai.

Peraturan Bupati Banyuwangi (2017) Nomor 26 Tahun 2017 tentang Perubahan Kedua atas Peraturan Bupati Banyuwangi Nomor 18 Tahun 2012 Tetang Tata Cara Pemberian dan Pemanfaatan Insentif Pemungutan Pajak Daerah dan Retribusi Daerah Kabupaten Banyuwangi

Rosdiana, H. (2018). Pengantar Ilmu Pajak: Kebijakan dan Implementasi di Indonesia.

Resmi, S. (2011). Perpajakan Teori dan Kasus Edisi 6 Salemba Empat.

Sudirman, Rismawati dkk. (2012). Perpajakan: Pendekatan Teori dan Praktik. Malang: Empat Dua Media.

Sugiyono. (2015). Metode Penelitian Kuantitatif, Kualitatif, dan R \& D. Bandung: Alfabeta.

Suandy, Erly. (2016). Hukum Pajak. Edisi 7. Jakarta: Salemba Empat 